\title{
《文心雕龍》文學批評範式研究 \\ On the Literary Criticism Paradigm of The Literary Mind and the Carving of Dragons
}

\author{
陶禮天 Tao Litian
}

DoI: http://dx.doi.org/10.7359/825-2017-taol

\section{摘要}

本文較為全面地討論《文心雕龍》的文學批評的總體原則和方法，即所謂《文心雕龍》的 文學批評範式問題，把《文心雕龍》的文學批評範式分析四種批評模式: (1)經典批評模 式, 是從文學的立場出發總結出儒家經典著作的特點作為文學批評的原則和方法, 在具體的 分文體的 “文學史論” 中, 也是選擇優秀的典範作品來總結寫作規範等問題。(2)才性批評模 式, 是把關於作家的才能和性格、性情之間的關係理論作為文學批評的原則和方法。(3)文體 批評模式, 是從文學的發展歷史出發去總結某類經典作品的文體特點作為文學批評的原則和 方法, 也是經典批評的具體體現和具體實踐。(4)知音批評模式, 它注重文學作品的文本分 析, 這是其原則和方法。如聽懂一位音樂家演奏的音樂才能去理解他的內心世界, 如果一 個批評家對作品文本具備這種鑒賞能力, 那麼他就是那位作家的 “知音”。

關鍵字：批評範式，經典，才性，文體，知音。

\section{Abstract}

This paper comprehensively discusses the overall principles and methods of the Wenxin diaolong literary criticism - namely, the issues of the Wenxin diaolong literary criticism paradigm - by identifying and analyzing four different patterns. The first is the classical literary criticism pattern: it derives from literature, as it takes features of the major Confucian literary classics as principles and methods for literary criticism, and draws composition norms and other related issues from the outstanding works and typical genres within the theory of literary history. The second is the Cai xing 才性 pattern: it considers the theories about the relationships with the author's talent, natural disposi- 
tion, and character as principles and methods for literary criticism. The third is the literary style criticism pattern: its principles and methods are drawn from the typical features of the classical styles of writing throughout the history of the literary evolution. It also represents the concrete expression and practice of classical criticism. The fourth is the Zhi yin 知音 (Appreciative critic) pattern: it emphasizes the textual analysis of the literary work that corresponds to its criticism criteria. This pattern tries to interpret the author's inner world of as though he were a musician expressing his talent in a musical performance. If a critic possesses this kind of literary sensibility and taste, then he could be the author's Z bi yin 知音 (Appreciative critic).

Keywords: criticism paradigm, classics, talent, literary style, Zhi yin.

一, 引 論

劉㑊的《文心雕龍》, 成書於西元五、六世紀之交的南齊末年 ${ }^{1}$ 。本文研究《文心雕龍》全 書所體現出的文學批評的原則和方法問題, 當然也包括其關於 “文學批評”之原理的分析, 但並不是如此前學術界在研究《文心雕龍》文學批評時, 主要致力於全書五十篇的所謂 “文 用” 論四十九篇的 “後五篇”, 即《時序》、《物色》、《才略》、《知音》、《程器》這五篇, 儘 管我也認為這 “後五篇” 可以統稱為 “文學批評論”。關於 “文學批評”的內涵, 學術界有不 同的解釋, 這裡略作說明。劉若思在《中國文學理論》開篇的 “導論”中說: “一般似乎都認 為文學的研究, 可以分為兩個主要部門——文學史與文學批評——雖然有時也分成三部分: 文學理論、文學批評與文學史。後者的分法中，“文學批評”事實上是指實際批評; 這種分類 至今仍未獲得普遍採納, 而許多作者仍然使用 ‘文學批評”一詞以包括理論探討與賽際批評 這兩者。” 並加兩條注釋, 說明 “三分法” 見於韋勒克與沃倫的《文學理論》, 美國M.H.艾 布拉姆斯所著《歐美文學術語詞典》關於 “文學批評”詞條解釋說: “文學批評是有關解釋、

1 清代學者紀昀、郝懿行、顧廣圻等均據《時序》篇而考定《文心雕龍》作於南齊。其後劉毓祬《通 誼堂集・書文心雕龍後》考定《文心雕龍》成書於南齊末年 (西元501-502年間), 今從之。學術界亦有 主張《文心雕龍》成書于梁初者。參見本《文心雕龍注》之《序志篇》注六, 《範文瀾全集》第四卷和第 五卷, 河北教育出版社 2002 年版, 第636頁。又所引《文心雕龍》文, 均據範文瀾此注本 (並參考其校 文), 不少地方重新增加了標點符號, 一般僅于文中直接標明篇名, 不再加注, 必要者另加注說明。又 本文引用書目, 凡同一版本之著作, 一般只于第一次引用時注明作者、出版年代與時間, 再次引用時, 只注明頁碼或卷次等。

2 參見 (美) 劉若愚: 《中國文學理論》 (Chinese theories of literature), 中譯本, 杜 國清譯, 江蘇教育出版社2006年版, 第1頁。按: 韋勒克與沃倫(Wellek and Warren)《文 學理論》關於 “文學理論, 文學批評和文學史” 的論述, 參見中譯本第四章, 劉象愚等 譯, (北京) 三聯書店1984年版, 第30-40 頁。 
分類、分析和評價文學作品的一種研討。” ${ }^{3}$ 本文所說的 “文學批評”，是作為與文學理論、 文學史相對而言的 “文學批評”，與上述M.H.艾布拉姆斯的解釋較為一致。事實上, 文學 批評是與文學理論、文學史論密不可分的, 所以英文literary criticism, 有時包括文學 理論和文學批評的意義，中國早期的 “中國文學批評史” 說的 “文學批評” 就是這個內涵。

本文討論《文心雕龍》文學批評範式, 堅持上述 “文學批評” 立場, 又兼顧《文心雕龍》 全書, 兼及《文心雕龍》的文學理論和文學史論, 將史、論、評三者結合起來討論問題 ${ }^{4}$ 。在 此, 我把《文心雕龍》的文學批評模式概括分析為四種, 各有所側重, 相互之間又構成一種 整體（這種整體性內涵我借用 “範式” 來表示）：即(1)經典批評模式一一其批評原則與方 法首先集中表述于 “文之樞紐” 的前五篇, 並作為思想原則貫徹於全書中, 尤其是體現為 文體批評模式中的 “選文” 批評的具體實践; (2)文體批評模式一一主要集中表述於 “論 文敘筆” 的二十篇文體論, 其原則與方法其實也是貫徹全書的; (3)才性批評模式一一主要 體現在其有關作家及其創作過程 ( “剖情析采” 部分) 的論述中; (4)知音批評模式——主 要體現為《文心雕龍》從創作和鑒賞角度對作品本身的一種 “文本分析”。每一種批評模 式中又系統地包括一系列具體的原則和方法, 而這些 “模式” 共同形成《文心雕龍》文學 批評的整體 “范式”，代表了中國六朝時期文學研究水準和理論思辨高度，而且涵蓋了前 人運用過的主要批評方法。

二, 範式的構成: 《文心雕龍》的四大批評模式

展開分析之前, 預先說明兩點: 一是本文從文學批評角度對《文心雕龍》相關篇章的概括 分析, 並不是說該篇只有我總結出的那幾點意思, 因為《文心雕龍》的文本內容是很豐富 的, 我可能只是側重在某個問題、某個方面來分析的, 這可能對我要論述的問題是最突出 的。說明這一點, 是為了避免引起不必要的爭論; 二是以下的分析論述, 限於篇幅, 也還僅 僅是綱領性的, 扼要性的。

\section{（一）經典批評模式: 五經皆文與宗經 “六義”}

這裡所謂經典批評模式, 就是指運用歷史上已經產生的被人們 (最少在知識界) 認可的 “文 學經典” 為批評標準, 來對後代的文學作品進行批評。《文心雕龍》文學批評的經典批評模 式, 就是指劉劦以儒家 “五經” 為標準, 來對其後的一切 “文”、“文學” 作品進行批評, 它 的理論闆述主要體現在《文心雕龍》“文之樞紐” 的前五篇中, 進而貫徹于《文心雕龍》全

3 (美) M.H.艾布拉姆斯:《歐美文學術語詞典》“文學批評”詞條, 中譯本, 朱金鵬、朱荔譯, 北京大學出版社1981年版, 第64頁。

4 按: 對《文心雕龍》全書的組成結構, 張少康師《劉䝵及其〈文心雕龍〉研究》一書第二章第二 節分析全面透徹, 本文大要也作如此理解。北京大學出版社2010年版, 第54-57頁。 
書一一因為全書都體現出一種 “選文” (選取各體文章的優秀的代表性的作品) 批評的特 點, 如果我們把《文心雕龍》論及到的 “選文” 編輯成書, 就是另一本與蕭統《文選》大體 類同的具有 “經典” 意義的 “文選”, 或者說是優秀作品選集。

《文心雕龍》前五篇是 “文之樞紐”, 是劉劦論文學之綱領, 當然屬於文學理論性質的, 它解決的文學理論問題, 主要就是關於文 “本” 論即文學的本體論 (《原道》)、文 “源” 論 即文學的歷史源流論 (《宗經》) 和文 “變” 論即文學的發展變化論 (《辨騷》) 等大問題。 從文學批評的立場看問題, 我們對《文心雕龍》前五篇還可以有更豐富的理解和分析。也 就是說, 《文心雕龍》前五篇的 “樞紐” 意義, 就文學批評而言, 概括地說, 就是建立起一 種經典批評模式, 主要包括其關於文學批評的合理性依據、正當性立場、價值判迦原則、 文學發展的合法性和基本批評標準，簡單說，就是合理性、正當性、價值性、合法性和準 則性這 “五性” 原則與方法——其圍繞的核心就是 “文” 要 “宗經”, 因為“五經” 是中國 歷史上存在的最早的 “文”，也是本原於 “道” 的 “文”。後代 “文” 皆源發於 “五經”, 經即 是文, 五經皆文。進一步簡析如下。

1, 合理性一一確立 “宗經” 和文學批評的合理性依據。《文心雕龍》的經典批評模式首 先體現為 “道、聖、經”三位一體的綱領, 論證了 “宗經” 的合理性。《文心雕龍》之《原道》 篇總結出 “道沿聖以垂文, 聖因文以明道” 的觀點, 體現出劉劦思文學研究的 “道、聖、經” 三 位一體的綱領, 也是其文學觀的集中體現, 如上所說, “道、聖、經” 三位一體的綱領的核心 是 “經”, 是 “文” 要 “宗經”; 其理論內涵就是: 道顯現于具體自然萬物和通過聖人之心而表 述於 “五經” (六經因 “樂經” 失傳而其實只有五經) 的都是 “文”，“文” 與 “章” 其語義之 一, 就是 “美”。文、文章或文學作為總名時, 包含 “文” (有韻) 和 “筆” (無韻), 一切 “文” 都必須是具有 “文” 的特性, 也就是說都是 “美” 的。

《原道》篇的思想實際本于《周易》(《易經》) 之《易傳》, 主要是《繫辭上傳》和《繫辭 下傳》。如果我們把《原道》與《周易》之《易傳》(《十翼》) 的《熬辭上傳》和《繫辭下傳》 對讀, 就會發現其思想和理論邏輯如出一轍。劉劦思所謂 “文之為德” 的 “文” 字, 從《原道》 篇 “人文之元, 肇自太極” 等思想來看, 主要當是運用的《周易・熬辭下傳》所謂 “物相雜為 文” 的思想 ${ }^{5}$ 。《原道》篇說:

人文之元, 肇自太極, 幽贊神明, 《易》象惟先。庖犧畫其始, 仲尼翼其終。而乾坤兩位, 獨 制《文言》。言之文也, 天地之心哉! 若乃《河圖》孕乎八卦, 《洛書》喡乎九疇, 玉版金鏤 之實, 丹文綠牒之華, 誰其屍之? 亦神理而已。

關於《河圖》、《洛書》的論述以及所謂 “神理” 觀念, 都是直接來自于《周易・熬辭上 傳》。 ${ }^{6}$ 《易傳》的文本具體完成時間大體在春秋戰國期間, 其中明顯吸取了老莊道家的

5 《周易・繫辭下傳》說: “易之為書也, 廣大悉備。有天道焉, 有人道焉, 有地道焉。兼三才而兩 之, 故六。六者非它也, 三材之道也。道有變動, 故曰爻; 爻有等, 故曰物; 物相雜, 故曰文; 文不當, 故 吉凶生焉。引據 (魏) 王昉注, (唐) 孔穎達疏: 《周易正義》, 北京大學出版社2000年版, 第375頁。

6 《周易・繫辭上傳》說: “是故, 易有大極, 是生兩儀, 兩儀生四象, 四象生八卦, 八卦定吉凶。…… 是故, 天生神物, 聖人則之; 天地變化, 聖人效之。天垂象, 見吉凶, 聖人象之。河出圖, 洛出書, 聖人則 之。”引據 (魏) 王貆注, (唐) 孔穎達疏: 《周易正義》, 北京大學出版社2000年版, 第3340頁。 
思想, 其 “自然之道” 的觀念並非出自儒家, 但 《易經》作為儒家的五經之一, 《文心雕龍》 中對此是沒有質疑的, 並且劉劦思接贊同前人 《易傳》為聖人孔子所作, 所謂 “仲尼翼其 終”。《老子》主張 “道法自然”, 《莊子》 繼承並發展之。《老子》書中有五處論及 “自然” 的概念, 都是 “自然而然” 的意思, “自然而然” 的本義就是 “本來的樣子”, 本來如此的自 在、自為的存在狀態與方式。所謂 “道法自然” 就是 “道” 以 “自然” 這種本來的狀態為 “效 法”、為屬性, 所以是 “自然之道”, 也就是說, 並沒有一個 “抽象” 的 “道” 的存在, “道” 存在於一切現象本身。《老子》分為 “道” 論與 “德” 論兩個部分 (故又稱為《道德經》) , 反復論述 “道” 為 “本體” 而 “德” 為現象和功用。 “德” 的本義就是 “得” 的意思, “得”之 於 “道”, 所以, “德” 為“道”之顯現的現象、功用。

劉劦思《原道》篇所謂 “文之為德也大矣”, 就是說 “文” 作為 (屬於) “道”之顯現的 “德” 是廣大的, 無所不在的。如前分析, “道” 就是天地自然萬物存在的本身的狀態與方式, “文” 是現象, 所謂 “本乎道” (《序志》), 而 “道” 是本體, 有天地萬物, 就有 “天文”、“地文”, 所 以說 “文” 是與 “天地並生” 的。其論證的邏輯清楚, 並不混亂。“自然”而有 “文采”, 是《文 心雕龍》的創作論的一個基本立場, 也是其文學批評的一個基本立場。而 “宗經” 和 “文源 於五經” 就是其 “經典批評模式” 的首要的原則與方法一一劉劦思正是通過 “原道” 的論析, 為其確立了合理性依據。

2 , 正當性一一確立 “宗經” 和 “文源於經” 的正當性立場。《文心雕龍》前五篇《原道》 、《征聖》、《宗經》、《正緯》和《辨騷》即所謂 “文之樞紐”, 其所體現出的一個重要原則和 判㫁立場一一就是 “五經皆文”。劉劦思將神聖的儒家 “五經” 稱之為 “經文”、“聖文”, 把它 作為最高的最為典範的 “文”。這在劉劦思看來, 並不是對五經的 “貶低”, 而是一種特別的推 崇, 其目的就是要為其 “宗經” 和 “文源於經” 的立場確立正當性的理論依據。從詮釋學的 立場看, 這反映了劉劦思的 “我注六經” 的思維方法, 表面上, 《文心雕龍》中似乎處處遵守儒 家經典的 “本義” 和 “原則” 的, 是 “我注六經” 的, 但事實上並非如此。

在劉劦看來, 五經皆文。對此, 在 “文之樞紐” 的五篇中予以反復論證和分析說明。那麼 劉劦思認為五經皆文, 主要有哪些具體內涵和文學批評的意義呢? 我認為主要有如下幾點:

第一，儒家聖人所製作的 “五經”，都是本源于 “自然之道” 的 “文”，“聖文” 就是聖 人的言辭, 除《易經》八卦符號外, 就是用文字書寫成的 “經文”。而 “六經” (實質只有五 經，下文不再說明）是經過孔子 “鎔鈞” (整理) 而成的。通過上文關於 “合理性” 的論證, 進一步說明了 “宗經” 的正當性。

第二, 聖人的經文成為後世一切文明、文化的原典, 成為教化百姓並且用之不竭的思想源 泉, 由此樹立起文學創作要遵守 “經文” 的原則——文以明道, 這也是劉劦思批評後世 (尤其是 晉宋乃至南齊時代 “訛濫” 文風 (《序志》) 的根據。《原道》說: 儒家經典 “莫不原道心以敷 章, 研神理而設教, ……觀天文以極變, 察人文以成化; 然後能經緯區宇, 彌綸彝憲, 發揮事 業, 虎炳辭義。故知道沿聖以垂文, 聖因文以明道, 旁通而無滯, 日用而不實。《易》曰: “鼓天 下之動者存乎辭。’辭之所以能鼓天下者, 乃道之文也。”聖人的經文是道之文, 是“因文以 明道” 的。

第三，“五經含文”論。文要 “宗經”，是因為 “經文”是有文采的，也是有 “文理” 的， 是美的, 是 “文勝其質” (見前引《原道》篇) 的典範。“文勝其質”, 勝, 是勝任、適當的意 思, 就是說 “文” 和 “質” (可以理解為內容與形式) 是相符的, 是統一的。《宗經》篇說: 
揚子比雕玉以作器, 謂五經之含文也。夫文以行立, 行以文傳, 四教所先, 符采相濟。邁德 樹聲, 莫不師聖; 而建言修辭, 鮮克宗經。是以楚澧漢侈, 流弊不還, 正末歸本, 不其懿粆!

範文瀾注引揚雄《法言・寡見篇》: “或曰: “良玉不雕, 美言不文, 何謂也? ’ “王不雕, 璵璠不作器; 言不文, 典謨不作經。” ”劉劦思經過解讀, 得出結論: “五經之含文也”——這 裡的 “含文” 是指 “符采相濟” 的文采。劉劦認為 “經文” (或曰 “聖文”) 的 “文” 是 “道 之文”, 其文的價值是無所不包的, 要結合如下幾點去認識。其結論就是: “論文必征於聖, 窺聖必宗於經。”(《征聖》) 理由充足, 具有正當性。

3, 價值性一一確立其文學批評的價值判斷原則。《文心雕龍》“文之樞紐”論的另一 個重大原則, 就是確立了文學批評的政治倫理教化的價值判斷維度, 並基本是貫徹全書 的。正是在這一點上, 最突出的體現了《文心雕龍》作為中國文學理論著作的獨特性, 體現 了儒家思想的指導性原則, 所謂 “經緯區宇, 彌綸彝憲, 發揮事業, 彪炳辭義”; 所謂 “寫天 地之輝光, 曉生民之耳目”。《序志》篇說: “唯文章之用, 實經典枝條, 五禮資之以成文, 六典因之致用, 君臣所以炳煥, 軍國所以昭明, 詳其本源, 莫非經典。而去聖久遠, 文體 解散, 辭人愛奇, 言貴浮詭, 飾羽尚畫, 文繡幋帨, 離本彌甚, 將遂訛濫。”也就是說: 文章 之“本” (儒家經典的本源) 的各種原則如果不遵守, 就變成 “浮詭”、“訛濫”之作, 就不能 做到使 “五禮”、“六典” 因文章而致用, 發揮不了 “君臣所以炳煥, 軍國所以昭明” 政治倫 理作用。《征聖》篇說: “然則聖文之雅麗, 固銜華而佩實者也。”創作要做到華實相符、文質 相勝, 情采統一, 就是在政治倫理教化作用這一價值判斷緯度下對文章寫作的基本要求。劉 劦思並不是從儒家五經的思想內容、觀點立場直接出發, 而是從五經皆是文章而且皆是典範 的文章的分析出發的, 這就使他的文學批評的價值判斷標準具有充足的合理性、正當性。

4, 合法性一一確立其文學發展變化論的合法性原則。《文心雕龍》的經典批評模式第 四個重要內涵就是確立文學發展之 “變” 的經典——這就是以屈原《離騷》為代表的《楚辭》 作品, 它與五經有同有異, 很好地處理了 “奇正”、“文質” 等關係, 是後代一切文學作品 “通 變” 歷史的 “典範”。騷體源於 “詩”, 是《詩經》的流變, 從文體類別上說, 屬於 “詩” 的下 屬一類, 所以學術界有人把 “騷” 判迦為其後面 “論文敘筆” 所論三十三種 “文體”並列的一 體, 也並非不可以; 但由於騷體已經成為 “文之樞紐” 的典範, 所以其上篇二十篇文體論就 以《明詩》為首, 不再討論 “騷體”, 但時時在多篇中論及 “騷體” 文學的典範價值。從文學發 展變化的角度看, 就存在一個是不是符合儒家思想原則的問題, 其實, 劉劦思多的是利用經 典批評作為衡量一切文學創作發展變化的思想原則而已。

首先, 劉氻思論證後代的文章本源於五經。《宗經》篇一口氣論述二十種文體都是源發於 五經的, 有 “文” 有 “筆”, 基本涵蓋了其後的 “論文敘筆”二十篇文體論的內容。但其實, 劉 劦思並非不知道 “論、說、辭、序, 則《易》統其首” 是不符合文學史實的, 他在《宗經》篇這樣 說的目的, 是強調儒家經典的權威性。

其次, 維護儒家經典和 “經文” 的尊嚴性。文學創作總是隨著時代的發展而發展變化 的, 這在《通變》篇中有充分地論述。在 “文之樞紐”中, 《征聖》、《宗經》和《正緯》三篇是 相互相成的關係, 其中心是《宗經》, 因為後人“征聖”只能通過 “宗經”來實現, 而 “正緯” 是因為讖緯學說有 “無益經典”的內容和意旨; 不過, 同時《正緯》篇與《辨騷》篇也可以視 為正反相成的兩篇。䜟緯之作, 不同于一般的文章, 它也是 “變”, 卻是 “偽經”。《正緯》篇 
嚴正地指出, 通過 “按經驗緯”, 䜟緯 “其偽有四”, 不過, 䜟緯文章中, “事豐奇偉, 辭富膏 膄, 無益經典, 而有助文章”, 所以 “後來辭人, 采摭英華”。這也是文學創作中既定的事實, 所以更有必要予以辨正。

最後, 確立 “變” 的典範——只有如《離騷》等 “楚辭” 作品, 才是符合文學發展、文學 創新的, 因為它能夠繼承儒家詩歌創作的 “風雅” 精神。所以, “辨騷” 就是辨 “騷”之變, 指 出其與 “經文” 相比, 有四同四異, 所以《辨騷》篇在 “文之樞紐” 中具有不可替代的決定性 意義。自漢代以來 “風騷精神” 就已經成為中國文學的重要傳統, 劉劦思通過《辨騷》篇不僅 廓清了楚辭批評史上的不正確的認識, 也為其文學發展變化論確定了基本原則, 進一步樹立 了《楚辭》與《詩經》一樣, 分別成為其後中國文學尤其是詩歌創作的南方文學與北方文學 的源頭, 這一源頭不僅是歷史的, 更重要的是精神的。雖然, “騷” 與 “經” 有四點不同, 但 多不是原則問題, 有的 “異” 還是劉劦思讚賞或基本可以認同的。《辨騷》所謂 “四異” 為:

至於托雲龍, 說迁怪, 豐隆求宓妃, 䲴鳥媒贱女, 詭異之辭也; 康回傾地, 夷羿彃日, 木夫九 首, 土伯三目, 譎怪之談也; 依彭鹹之遺則, 從子胥以自適, 狷狹之志也; 士女雜坐, 亂而不 分, 指以為樂, 娛酒不廢, 沉湎日夜, 舉以為歡, 荒淫之意也: 摘此四事, 異乎經典者也。

所謂 “詭異之辭” 和 “譎怪之談”, 這正是《離騷》等楚辭作品成為 “奇文” 的原因, 而劉劦思 其實愛 “奇”, 讖緯之作的 “事豐奇偉”, 他都可以就創作角度加以稱讚, 那麼這兩種與 “經 文” 的不同, 就不是完全的貶抑之意了。而 “狷狹之志” 雖不符合儒家之 “中道” 原則, 但《論 語》中孔子對狂狷行為也不是完全否定的; 至於 “荒淫之意” 的論述, 也不能一概否定, 是 要具體地歷史地看的, 如其《明詩》篇, 論建安文人時說: “並憐風月, 狎池苑, 述恩榮, 敘 酣宴” 云云, 明顯是讚賞的態度。至於 “四同”——所謂 “典誥之體”、“規諷之旨”、“比 興之義” 和 “忠恕之辭”, 這正是儒家所宣導的 “風雅” 精神的最重要的要求, 所以劉劦思明 言: “同於《風》、《雅》者也。” 劉劦思對屈原和他的作品充滿了讚美和敬佩之情, 《辨騷》開 篇就說: “自《風》、《雅》寢聲, 莫或抽緒, 奇文秷起, 其《離騷》哉! 固已軒翥詩人之後, 奮 飛辭家之前, 豈去聖之未遠, 而楚人之多才乎! ” 又說: “氣往轢古, 辭來切今, 驚采絕鄷, 難 與並能矣。”他總結出文學的繼承和發展應有的原則就是：“酌奇而不失其貞 (正)，玩華而 不墜其實”, 這與他總結 “經文” 的 “銜華而佩實” 的品質, 是一致的。

5, 準則性一一確立其文學批評的基本標準。《文心雕龍》“文之樞紐” 論, 從文學批評 角度來說, 就是總結出作為創作原則和方法的 “六義”。《宗經》篇說:

故文能宗經, 體有六義: 一則情深而不詭, 二則風清而不雜, 三則事信而不誕, 四則義貞而 不回, 五則體約而不無, 六則文麗而不淫。

這 “六義” 就是經典批評的具體原則和批評標準, 貫徹於全書的批評精神中, 但同時我要 非常強調的一點就是: 由於 “經” 也是 “文”, 劉劦思確立的這一文學經典批評方法, 實際上 雖然起到一種政治倫理價值判斷的功能, 但更重要的是從 “文” 出發, 從 “美” 出發, 使之 能夠與其它批評原則和方法一起, 同時也成為一種重要的 “審美” 批評, 共同成為全書的 一種整體批評範式的內容。只是經典批評模式在《文心雕龍》全書中具有一定的指導思想 的立場意義, 其地位是首要的。 


\section{（二）才性批評模式: 才性統一與風格 “八體”}

所謂《文心雕龍》的才性批評模式, 就是指劉劦思從作家 “才” (實際包括才、氣、學、習這 四個方面的內容) 和 “性” (個性、性情) 關係出發, 對作家進行深入研究和批評, 並從作家 的 “才性” 與作品的 “體” (風格等方面) 的關係乃至 “心物” (主客觀) 關係等創作論角度, 對文學作品進行批評研究, 這種原則和方法也是貫徹《文心雕龍》全書的。其中也包含諸多 重要的具體批評原則和方法。

才性批評可以說是中國傳統文學批評具有非常鮮明而且影響至今的最重要的文學批 評理論, 這一文學批評模式建構完成於六朝時期, 運用最為成熟、論述最為全面的代表著 作就是劉劦思的《文心雕龍》。在此, 我想簡要討論兩個方面的內容: 一是才性批評的豐富 的理論基礎、基本觀點, 只有把這個問題弄清楚, 才能把《文心雕龍》才性論分析明白; 二 是對《文心雕龍》才性批評的原則、方法和突出特點加以歸納分析。

1 , 《文心雕龍》才性批評模式的豐富的理論基礎。才性論是六朝時期 “清談”、人物品評 和玄學的主要論題, 其思想淵源可以追溯至先秦時期, 正如漢魏之際的劉邵 (字孔才) 《人物 志序》所謂 “仲尼不試無所援升, 猶序門人以為四科, 泛論眾材以辨三等” 7 。不過, 清談、玄 學所深入討論才性關係的時代是在魏晉時期, 其代表人物有傅嘏、李豐、王廣和鐘會, 主要 包括才性同、才性異、才性合、才性離這 “同、異、離、合” 四種觀點; 鐘會曾作《四本論》, 而 鐘會本人是主張 “才性合” 的觀點的; 根據《三國志・魏書・傅嘏傳》記載, 傅嘏 (字蘭石), 嘗 “論才性同異”。這大體可以說明, 不管是主張才性的 “同、異、離、合” 哪種觀點, 大概在 清談讋論或著述成文時, 都會論及其他的觀點。劉劦思著《文心雕龍》不僅運用了才性理論, 而 且他對有關才性的思想文獻也是熟悉的, 其《論述》篇明確評論到 “蘭石之《才性》”, 並加 以稱讚。才性論不僅是當時辨析名理的玄學思潮中的主要論題, 其後也對當時的宗教佛教、 道教思想也產生了重要影響, 而在文學批評中早在劉劦之前就較為廣泛地使用才性批評的 原則和方法。這也說明六朝時期玄學、宗教思想等與文學批評之間是相互作用和影響的。

第一, 先論述才性四本論即 “同、異、離、合” 的具體理論。南朝梁時, 劉孝標注《世說 新語》該條, 引《魏志》曰:

會論才性同異, 傳於世。四本者: 言才性同, 才性異, 才性合, 才性離也。尚書傅嘏論同, 中 書令李豐論異, 侍郎鐘會論合, 屯騎校尉王廣論離。文多不載。 8

陳寅恪先生曾撰《書世說新語文學類鐘會撰四本論始末條後》一文, 主要是要說明如下三 點: (1)主張才性 “同、異、合、離”之論與魏亘之際曹氏與司馬氏政治上的派別分野和鬥爭 有關, 當時正值魏明帝 (曹颚) 及齊王 (曹芳) 時期, 司馬懿和司馬師、司馬昭父子正在積聚 勢力積極謀取政權。(2)結合《世說新語》和《三國志》等記載, 說明主張 “才性同” 的傅嘏

7 (魏) 劉邵著, (西涼) 劉昞注: 《人物志》, 引據《風俗通義・獨斷・人物志》合刊本, 上海古籍 出版社1990年版, 第2頁。

8 (南朝宋) 劉義慶著, (南朝梁) 劉孝標注, 餘嘉錫箋疏: 《世說新語箋疏》之《文學》篇第 4 條, 中華書局2011年版, 第170頁。 
與主張 “才性合” 的鐘會, 是屬於司馬氏的同黨, “其持論與東漢士大夫理想相合”一一按: 因為司馬氏至少在政治宣傳上是主張使用才能和品性統一的人才, 宣揚儒家的名教思想的; 主張 “才性異” 的李豐和主張 “才性離” 的王廣、王淩父子是屬於曹氏的舊党, 是司馬氏的敵 政, 其持論與曹操 “求才令之主旨符合”。李豐和王淩父子後來均因謀求反對司馬氏 (司馬 師、司馬昭) 被殺。這就是說: 合同論為一派, 離異論為一派。(3)大名士、名辯高手、也是著 名的作家嵇康, 乃曹操的曾孫婿 (據《三國志・魏志》之《曹林傳》裴注引《嵇氏譜》), 政治 上與司馬氏不合作, 故後來終於為黨同司馬氏的鐘會所害。那麼才性之 “同、異、合、離” 大 體是什麼意思呢? 萬繩南先生《魏晉南北朝文化史》有關考述較為明白。9 我們大體可以把 才性 “同、異、離、合”四說的基本觀點, 作如下簡要總結:

合同派:

才性同一一主張才性一元論, 性就是才, 才就是性, 把人的內在的天賦、秉性、 品行與人的才能、功用 “同一”起來, 認為內外完全一致;

才性合一一因為才性同之說明顯有缺陷, 在現實社會實踐中, 存在人的品性高 尚而才能卻可能平庸的事實, 受到離異派的影響, 才性合主張才性是二元的, 但 畢竟也存在品行高尚而且才能也很高的人, 選人用人, 應該選拔使用這樣才性 相合 (一致) 者, 而品性不端者, 即使其有大才也絕不能使用。

離異派:

才性異一一主張才性二元論, 性不是才, 才不是性, 不可把才與性等同起來; 才性離一一主張才性二元論, 其新意在於, 既然天賦秉性端正者可能是庸才, 而性情不符合道德標準者, 可能有治國理政的大才, 那麼就選人用人而言, 應該唯才是舉, 不用去考慮品性善惡好壞, 至少不作為必要的準則, 用人而用 其 “才” 即可。

第二, 劉妿思撰《文心雕龍》之前, 才性論已經成為文學批評中的一種較為普遍的分析 方法, 這對劉鞇當會產生較為直接的影響。如曹不的《典論・論文》、陸機的《文賦》等。

2 , 劉愢《文心雕龍》才性批評的原則和方法。這種才性批評模式, 具有一定的 “心理” 批 評、語言形式批評的特點, 同時它又與經典批評模式、文體批評模式相結合, 體現為多方面的 特點。《文心雕龍》的才性批評模式的原則與方法, 簡要地說, 我以為主要有如下幾個方面。

第一, 劉箅《文心雕龍》主要吸取和贊同才性論的 “合同”派的理論主張, 從創作角度 思考問題, 提出了 “才、氣、學、習” 的系統理論, 這是從 “性” 和 “才” 兩個方面作出了新 的系統論述, 把作家的情性與 “才、氣、學、習” 綜合為 “內” 的因素, “隱” 的因素, 把作品 表現出的個性特點作為 “外” 的表現, 由此把這一基本觀點, 作為作品個性特點和風格特 點乃至審美理想的批評原則和方法。其《體性》篇開端就說:

夫情動而言形, 理髮而文見, 蓋沿隱以至顯, 因內而符外者也。然才有庸俊, 氣有剛柔, 學 有淺深, 習有雅鄭, 並情性所鋢, 陶染所凝, 是以筆區雲譎, 文苑波栬者矣。故辭理庸俊, 莫能翻其才; 風趣剛柔, 寧或改其氣; 事義淺深, 未聞乘其學; 體式雅鄭, 鮮有反其習: 各 師成心, 其異如面。

9 萬繩南: 《魏晉南北朝文化史》, 東方出版中心2007年版, 參見第46-49頁。 
其《明詩》也說: “人禀七情, 應物斯感, 感物吟志, 莫非自然。” 認為作家由 “性情” 和 “才 氣” (實際上包括才、氣、學、習四個主要方面內容) 構成所謂的 “內”, 這與作品的 “外” (即 作品的個性特點和風格特色）是統一的。《文心雕龍》中對不同作家的才性論述, 可謂灌注 在所有有關作家作品的分析之中, 展開了豐富的多方面的論述。

第二, 劉罳《文心雕龍》的才性論是“通才”論和 “偏才” 論的結合, 其對文學批評的重 要意義在於突出強調了作家的個性創作和批評研究。劉邵《人物志・九征》說: “蓋人物之 本; 出乎情性”, “禀陰陽以立性, 體五行而著形。”從 “性情”之辨出發論及人物的才性異 同。劉邵《人物志》在《體別》、《流業》、《材理》、《才能》諸篇中, 進一步分析了 “五常既 備, 包以澹味” 的聖人 “中庸”之性, 認為一般常人均有偏至之性而具偏至之才, 偏至才性的 人, 各有擅長之才能, 其中羅列了十二種偏至才性的得失、十二種人材相宜的 “流業”。劉媤 也反復申述了 “才性異區, 文辭繁詭” (《體性》) 的觀點, 《才略》篇從 “九代之文” 說到 “宋 代逸才”, 討論歷代著名文人作手的 “性各異禀” 的個性與風格, 補充了《神思》、《體性》 諸篇觀點, 在文學理論上具有十分重要的價值。不同作家的作品個性特點之所以不同, 正 是由於作家的才性有 “偏至” 造成的。

劉㽝《文心雕龍》一個傑出的貢獻, 就在於強調創作個性一一這正是從才性批評角度 提出的深刻論題。《明詩》篇說: “然詩有恆裁, 思無定位, 隨性適分, 鮮能通圓。”- - 這 不是貶義的批評, 而恰恰是他最值得重視的意見, 是一種正面的立論, 認為詩人應按照自 己“性分” (獨特的才性) 去創作，去“隨”之、“適”之，這就是要求作家把握住自己的個性 和所長。

第三, 劉裉《文心雕龍》一個特別重要的理論創新在於論述文體的客觀性質的 “體勢” 與作家才性特點的相互調適問題, 這也是從 “隨性適分” 論的邏輯分析而合理地推論出來 的理論主張。其《定勢》篇認為:

夫情致異區, 文變殊術, 莫不因情立體, 即體成勢也。勢者, 乘利而為制也。如機發矢直, 澗 曲湍回, 自然之趣也。圓者规體, 其勢也自轉; 方者矩形, 其勢也自安: 文章體勢, 如斯而已。

這說明文體以及按照某種寫作之時所存在的一個客觀的文體特點與作家主體才性的統一 性問題, 而且作家主體在長期的學習過程中, 也會存在個性的變化和習慣問題, 二者要能 夠有機結合, 才能創作出優秀的作品。

第四, 以“八體” 說概括文學作品的基本風格類型, 論述風格的相反相成的特點, 也是 對傳統才性論的繼承和發展。《體性》篇說:

……若總其歸途, 則數窮八體: 一曰典雅, 二曰遠奧, 三曰精約, 四曰顯附, 五曰繁縟, 六曰 壯麗, 七曰新奇, 八曰輕靡。典雅者, 熔式經誥, 方軌儒門者也; 遠奧者, 馥采曲文, 經理玄 宗者也; 精約者, 核字省句, 剖析毫釐者也; 顯附者, 辭直義暢, 切理厭心者也; 繁縓者, 博 喻釀采, 煒燁枝派者也; 壯麗者, 高論宏裁, 卓焓異采者也; 新奇者, 擯古競今, 危側趣詭 者也; 輕靡者, 浮文弱植, 縹紗附俗者也。

根據上文分析, 我們現在可以知道: (1)這八體是作家根據自己的才性又與具體文體的體 勢 (文體風格和文體機制特點) 相互調適、相互作用而形成的; (2)是與文學傳統的學習和 
傳統的作用力有關的, 《定勢》說: “是以模經為式者, 自入典雅之懿; 效《騷》命篇者, 必 歸鄷逸之華; 綜意淺切者, 類乏醞藉; 斷辭辨約者, 率乘繁縟: 譬激水不渏, 楟木無陰, 自 然之勢也。”(3)這 “八體” 是相反相成的, 猶如《周易》所說的 “八卦”, 是各種風格的基 元, 它們相互不同的結合, 可以體現作家作品的千變萬化的風格特色, 因此說: “故雅與奇 反, 奧與顯殊, 繁與約多, 壯與輕乘, 文辭根葉, 苑直其中矣。” (《體性》) 可見, 《文心雕 龍》的才性批評模式具有理論的豐富性和方法論的多元性特點。

第五, 劉劦思《文心雕龍》的才性批評論主要採用的是 “合同”一派的觀點, 但對 “離異” 一派的思想也有所借鑒。這一點也是有必要明確指出的, 因為劉劦思《文心雕龍》在才性批評 上類同於才性四本論的 “合同”一派是比較顯豁的, 而他實際上也吸取了 “離異” 派的理論 資源, 我們往往會忽略這一點。劉劦思在才性關係問題上, 是二元論者而非一元論者, 這點是 明確的。《程器》篇明確說:

蓋人禀五材, 修短殊用, 自非上哲, 難以求備。然將相以位隆特達, 文士以職卑多誚, 此江河 所以騰湧, 涓流所以寸折者也。

學術界多從劉珈思同情文人的角度去理解問題, 以為這是在為曹不提出的作家具有 “文人相 輕” 等毛病進行辯護, 其實重點不在這裡。關鍵問題在於 “人禀五材, 修短殊用”, 除了聖賢 之外, 就一般文士、文人來說 (當然也包括武人乃至所有的人), 性情品行有不完美 (不善) 是客觀存在的, 但這並不完全決定其不能成為作家, 決定其不能寫出好的作品, 甚至也不完 全決定其不能成為大作家, 寫出很優秀的作品。這正反映出了劉劦思的識見之高, 是他把玄學 的才性論具體運用到文學批評上的一種理論發展, 是基於具體的文學創作與文學批評實踐的 一種理論創新。《程器》篇明確舉出文士 (作家) 的性行品德的才性之 “性” 的瑕疪和缺陷。

漢代揚雄《法言・問神》篇說: “故言, 心聲也; 書, 心畫也。聲畫形, 君子小人見也。”10 但這只能是一種應該如此的理想狀態。金元時著名文學家元好問在其《論詩三十首》（之六） 中就說: “心畫心聲總失真, 文章窝複見為人。高情千古閒居賦, 爭信安仁拜路塵。” ${ }^{11}$ 本來 孔子就說: “有德者必有言, 有言者不必有德。仁者必有勇, 勇者不必有仁。” 12 如果說作品 類同於一個人運用才能創作出的 “言” , 暫且不論 “有德者必有言” 這一論斷是否成立, 至 少 “有言者不必有德” 是可以成立的。但畢竟從總體上, 從理想上來說, 才性統一最好, 這 就符合 “才性合” 的觀點。從文學史上看, 那些真正偉大的作品, 一定是 “為情而造文” 的, 真實性是文學的生命。不過, 同時從文學批評看, “為文而造情” 的現象既然存在, 至少在理 論上不能說才性是具有 “同一”性的, 而是 “統一” 性的。

第六, 劉劦思《文心雕龍》才性論具有類型化的傾向, 這不僅是對作家的分析, 也包括對 讀者的分析, 具有一定的理論預設性色彩。如《體性》篇所謂 “是以賈生俊發, 故文潔而體 清” 這一大段論述, 在邏輯上, 這裡確實包含一種類型化的思維方法, 因為才性 “俊發” 與

10 (漢) 揚雄著, 汪榮寶義疏: 《法言義疏》, 陳仲夫點校, 中華書局1987年版, 第160頁。

11 (金) 元好問著, 狄寶心校注: 《元好問詩編年校注》(第一冊), 中華書局2011年版, 第51頁。

12 (魏) 何晏注, (宋) 邢旵疏: 《論語注疏》卷 14 《憲問第十四》, 《十三經注疏》整理本第 23 冊, 北京大學出版社2000年版, 第207頁。 
作品 “文潔而體清” 的特點, 才性 “傲誕” 與 “理侈而辭溢” 的特點等等, 只是一種大概的分 類, 而且不是必然的。比如陸機 “矜重”, 故其文風格就表現為 “情繁而辭隱”; 可是我們覺 得 “矝重” 的人, 也許也能夠寫出 “情簡而辭顯” 等風格特點的作品。

總之, 才性批評還要跟其他批評原則和方法結合起來才更為有效, 其實劉劦就是這樣 做的, 這也是《文心雕龍》的高明之處。才性理論是中國固有的非常獨特的思想, 才性批評 是中國文學理論與批評的一個非常重要的普遍的文學批評原則和方法, 對今天文學研究仍 然具有重要的價值, 仍然可以為我們今天的文學研究所借鑒和運用。

\section{（三）文體批評模式: 歷史原則與 “文學” 史論}

所謂《文心雕龍》文體批評模式, 主要是指是從文學的發展歷史出發總結某類經典作品的 文體特點, 作為這類文體寫作的批評原則和方法。劉劦《文心雕龍》把所有文體分為有韻 之 “文” 和無韻之 “筆” 兩大類, 共討論了三十三大類的文體, 不少文體下面又討論其衍生 出來各種小的文體類別。文體批評模式不僅體現在二十篇文體論中, 也體現在全書其它各 篇之中。它主要體現為四種原則和方法, 這就是其《序志》篇所說的 “原始以表末, 釋名以 章義, 選文以定篇, 敷理以舉統”, 我們可以用 “原、釋、選、敷” 四字來概括。在我看來, 這 四種方法圍繞的中心和具體分析內容, 實際就是一種文學史論, 同時, 也是一種文體批評。 這種文體批評最為重要的方法就是 “選文” 批評方法, 而如前所說, “選文” 批評方法, 本 質上也是一種 “經典批評”，體現了一種 “經典” 批評的原則和方法。

所以前文說, 本文所總結歸納的《文心雕龍》四大批評模式是系統的, 整合在一起的, 相互作用, 相互影響, 我把它統稱為批評範式。為什麼說 “原、釋、選、敷” 的方法, 主要就是 一種文學史論, 是一種文體批評模式呢? 因為 “選文” 是一種優秀作家作品的具體的文學歷 史過程的體現, 所謂 “原始以表末”一一實際上就是一種歷史批評; “釋名以章義”一一實 際上就是源於儒家的一種 “正名” 批評, 目的也是為具體的文體及其後來衍生發展進行正本 清源; “敷理以舉統” ——就是一種從歷史分析中進行歸納的批評方法, 是一種文學理論的 總結和昇華, 其目的就是為具體文體的創作樹立規範。當然, 我們今天把《文心雕龍》二十 篇 “論文敘筆” (文體論)，視為一種分體的文學史論，這是從我們今天的文學史學的角度去 看問題的。從這個角度看, 從《文心雕龍》具體批評分析看, 文學史研究從某種意義上說, 也是一種歷代文學作品的 “精華錄”; 同時, 文學史從某種意義上說也是一種文學批評史， 文學史的書寫不能離開文學批評, 因為文學史不是流水帳的紀錄, 它貫徹著歷史主義的源 流正變原則。鑒於上述考慮, 在此主要討論兩個問題, 一是《文心雕龍》文體批評的文學 史觀和歷史批評原則與方法, 二是其文體批評的 “選文” 原則和方法。

1 , 《文心雕龍》的文學史觀及有關批評原則和方法問題。《文心雕龍》的 “論文敘筆” 部分, 歷來被視為文體論。《梁書・劉劦思傳》說: “......劦思撰《文心雕龍》五十篇, 論古今文 體, 引而次之。”這似乎是把《文心雕龍》視為兩個部分, 一是 “論古今文體”, 主要是上篇; 二是 “引而次之”, 可以包括下篇對創作論等內容, 從總體上論 (各種文體) 作品的創作等 問題。可是到《南史・劉劦思傳》就把 “引而次之”刪除了, 因為“引而次之”確實可以理解為 對各種文體依次而論述之並分析其創作的種種問題等。總之, 這說明在很長的一段歷史 
時期，《文心雕龍》是被人們視為論古今各種文體作品及其寫作問題的。“古今” 就是歷史 發展的過程, 要討論古今歷史發展過程中各種文體的發展, 其實質就是一種分體的文學史 論——不是文學史, 而是文學史論, 就包含著批評。所以, 我們研究《文心雕龍》的文體批 評模式問題, 首先就是它的文學史觀和文學史的批評原則和方法, 除去前文在論析經典批 評模式討論其 “文之樞紐” 所論述的文學本體論、本源論和發展論——即我概括的文 “本” 論、文 “源” 論和文 “變” 論外, 我以為《文心雕龍》的進一步閭釋論述, 還主要包括: “通 變” 的歷史論, “時序” 的社會論, “物色” 的自然論, “才略” 的才性論, “程器” 的功用論 等內容。其實，關於文學史觀問題，劉劦思在 “文之樞紐” 論中已經交待了其 “綱領” 性的意 見, 綱領畢竟是綱領, 還需要具體的更進一步的闡述, 才能把問題深入剖析清楚。從文學批 評出發, 統觀《文心雕龍》全書, 我以為要強調這樣幾點: 首先, 第二十九篇《通變》是專門 闠發其文學歷史發展觀的; 其次, 在 “文用” 論四十九篇中的 “後五篇”——《時序》、《物 色》、《才略》、《知音》和《程器》這五篇, 屬於較為集中的文學批評論, 其間體現出的歷 史批評觀念和方法, 與《通變》篇一樣, 是一種直接的 “原理性” 闡述分析; 又次, 在下篇 討論創作論、文術論——雖然從今天的文學批評的眼光看, 關於作品之文本論述的文術 論部分, 主要屬於一種 “文本批評”, 但都貫注了其文學史觀, 處處體現著劉劦思的強烈的歷 史批評意識; 最後, “論文敘筆”二十篇中是其文學史觀主要的落實和體現, 是其文學史論 的主要的具體篇章內容。正如我們一再強調的, 研究《文心雕龍》的文學批評必須統觀全 書, 才能完整地把握其 “批評範式”。

第一，“通變” 論——歷史批評論。我認為劉劦思 “論文敘筆” 的一個重要的歷史文化 貢獻就是在儒家之道的思想原則指導下, 論述了中國傳統文學的各體優秀作品的歷史譜 系, 從而他從 “論文” (《序志》所謂 “經典枝條” ) 的研究領域, 有力地也是有效地延續 了中國文化傳統的命脈和精神, 這是劉劦《文心雕龍》文學史論的傑出貢獻。《通變》說:

夫設文之體有常, 變文之數無方, 何以明其然耶? 凡詩賦書記, 名理相因, 此有常之體也; 文 辭氣力, 通變則久, 此無方之數也。名理有常, 體必資於故實; 通變無方, 數必酌於新聲; 故 能駎無窮之路, 飲不竭之源。然綆短者銜渴, 足疲者輟途, 非文理之數盡, 乃通變之術疏耳。

首先, 在劉劦思看來, 文體之 “體” 是相對穩定的, 因為一種文體形成規範後, 其 “名理” (一定體 式、體制和規則）就需要作家去學習, 去掌握, 否則就不可能寫出符合這種 “明理” 的文體 作品; 而 “文體”之 “文” 是因人而變的, 否則也就不是新作, 所以說 “通變” 的規律, 也是 一種為文之 “術” (規則和方法)。其哲學理論基礎就是《周易》的通變觀、常變觀, 儒家 的 “經權” 觀。

其次, 劉氻思從 “文質” 和 “雅俗” 兩個緯度去通觀歷代文學的發展, 所謂 “規略文統, 宜 宏大體”, 這裡的 “文統”, 一般注家多解釋為具體文章的寫作要領, 我認為是有這個 “本義” 的, 其主要內涵就是 “文質” 和 “雅俗” 兩個 “大體” 的方面, 具體地落實講, 包括如 “詩、 賦、書、記” 等文體的 “名理” 的把握和 “文辭氣力” 的 “無方之數” 的內涵, 但這只是一個 方面; 另一個方面, 這裡的 “文統”, 也還包括歷代文學創作和具體作品的形成的從 “文質” 和 “雅俗”兩個緯度所形成歷史的統緒——具體文體的典範作品構成的文學史系列的譜系 及其作品特點, 這是比較接近後來中國傳統文學批評中的“文統”概念的。雖然劉恊思並沒有 
突出強調這個 “文統” 的意義 (如唐代韓愈和後來的古文家們), 但他的二十篇文體論的具 體批評, 事實上起到了這種作用, 尤其是其 “文之樞紐” 論的精神體現了這種歷史性的儒 家 “道統” 和 “文統” 意識。長期以來, 似乎學術界不願意承認這一點, 似乎承認這一點就 容易被人 “誤解” 為是把唐宋及其後的古文家的理念強加到用駢文寫作的劉劦思身上, 其實 無視這一點, 才是不符合《文心雕龍》的精神的, 也是不符合劉劦思論述的理論內涵的。駢文 只是《文心雕龍》理論批評的話語形式, 而其表述的思想內容才是最主要的, 這是非常明白 的道理。因此, 我們實在沒有必要也沒有理由擔心這種 “誤解”。

又次, 劉劦思的文學史觀總體而言, 是《周易》的 “日新” 論, 即主張文學要隨著時代的發 展而發展的, 而不是退化論、保守論、循環論, 也不是什麼進化論。《通變》篇說:

搉而論之, 則黃唐淳而質, 虞夏質而辨, 商周麗而雅, 楚漢侈而灎, 魏晉淺而綺, 宋初訛而 新。從質及訛, 彌近彌澹, 何則? 競今疏古, 風昧氣衰也。

贊曰: 文律運周, 日新其業。變則可久, 通則不乏。趨時必果, 乘機無怯。望今制奇, 參古定法。

從上引第一段看, 我們確實可以認為劉劦思的文學史觀是退化論和保守論, 但我們結合上引 的 “贊曰”一段和全書特別是 “論文敘筆” 二十篇看, 我們又會發現其實他的主要意思是 “日 新” 論。這種好像矛盾的論述如何理解呢? 合理的解釋: 一是 “從質及訛, 彌近彌澹” 僅僅是 從 “文質” 和 “雅俗” 的角度看的, 這在劉劦思看來是符合文學發展的歷史事實的, 而他對於作 家關於 “文質” 和 “雅俗” 關係的處理原則是 “通變” 的一一所謂 “斯煁酌乎質文之間, 而彩 括乎雅俗之際, 可與言通變矣。” 可見劉劦思理論之通達。二是他是針對 “近代” 和當代 (主要 就是南朝宋齊時期) 文學創作的訛濫文風來立論的, 所謂 “今才穎之士, 刻意學文, 多略漢 篇, 師範宋集, 雖古今備閱, 然近附而遠疏矣。”(《通變》)

第二, “時序” 論——社會批評論。如前所說, “文用” 論之 “後五篇” — 《時序》、《物 色》、《才略》、《知音》和《程器》屬於文學批評論, 有人不解這五篇為什麼放在一起, 並從 現代的文學創作論出發, 認為至少《物色》篇是應該屬於創作論, 於是出現調整《文心雕龍》 篇次的論析, 其最初始于範文瀾的《文心雕龍注》。這並不是不可以這樣分析, 因為《物色》 篇確實論述了創作論中的 “心物” 關係問題——而這實際上是文學創作論的中心問題; 但這 樣調整沒有任何版本依據, 而且解釋也是過於現代的。其實這 “後五篇” 集中在一起, 形一 組有共同性的論述中心, 這就是文學批評及其原理的分析, 文學批評自會涉及創作問題, 而 且這是《文心雕龍》以及中國傳統文學理論與批評的特色。

《時序》篇論述了“蔚映十代, 辭采九變”的文學發展過程, 其主要觀點就是說文學創 作的 “古今情理”, 是隨著時代發展和社會現實情況而發展變化的, 所謂 “故知文變染乎世 情, 興廢系乎時序, 原始以要終, 雖百世可知也。”這是一種自覺的歷史批評。其中主體部分 對中國 “十代” 文學發展從 “文質” 等方面的具體分析, 最有價值。

第三, “物色” 論——體物批評論。《物色》所謂 “吟詠所發, 志惟深遠, 體物為妙, 功在密附”, 所以我們可以把這種角度的批評方法稱之為 “體物批評論”。《物色》說:

且《詩》、《騷》所標, 並據要害, 故後進銳筆, 怯於爭鋒。莫不因方以借巧, 即勢以會奇, 善 於適要, 則雖舊彌新矣。是以四序紛回, 而入興貴閑; 物色雖繁, 而析辭尚簡; 使味飄飄而 
輕舉, 情曄曄而更新。古來辭人, 異代接武, 莫不參伍以相變, 因革以為功, 物色盡而情有 餘者, 曉會通也。若乃山林臬壤, 實文思之奧府, 略語則關, 詳說則繁。然則屈平所以能洞 監《風》、《騷》之情者, 抑亦江山之助乎?

中國文學抒情傳統一個最大的特點, 就是以景寫情, 借景抒情, 情景交融是中國文學自《詩 經》和《楚辭》以來最大的特點, 《物色》篇也是以此來作為典範進行討論的, 這種傳統在 創作方法上就是 “賦比興” 尤其是 “比興” 的運用, 這裡也就涉及到具體的 “通變” 問題。 當然《物色》篇, 和其他《文心雕龍》各篇章一樣, 可以有更為豐富的討論, 發掘更多的理論 資源, 但這是另一個論題。前文已經強調, 我們在此是從文學批評看問題的。

第四，“才略”論——歷代作家作品的突出的個性特點和成就論, 前文論才性批評模 式時, 已有所討論。

第五, “程器”論——作家理想要求和作品現實功用論, 前文也已經有所闡明, 限於篇 幅, 此處就不再展開論析。

2 , 文體批評模式的核心原則和方法—— “選文” 批評。“論文敘筆”二十篇文體論具體 篇章的主體內容, 如前所說, 每篇所論文體就是在 “原始表末” 的歷史發展論中, 通過 “釋名 以章義” 對所論文體及其衍生文體的名目進行 “正名” 批評, 通過精心選擇歷代作家作品構 成鮮明的一種分類的文體作品發展史，並由此來論析具體一種文體的規範、體制、體式乃至 創作原則。在具體的論述中, 充分運用了經典批評、才性批評以及下文要論析的知音批評等 原則和方法。比如《明詩》篇, 先從 “釋名以章義” 開端說：“大舜云：“詩言志, 歌永言。’ 聖 謨所析, 義已明矣。是以 ‘在心為志, 發言為詩’, 舒文載實, 其在茲乎! 詩者, 持也, 持人情 性; 三百之蔽, 義歸 “無邪”, 持之為訓, 有符焉爾。人稟七情, 應物斯感, 感物吟志, 莫非 自然。”接著從最早見於歷史傳聞記載的 “昔葛天樂辭”，論述到 “宋初文詠”，分析了歷 代詩歌創作的發展情況，並結合時代、社會現實情況等予以深入分析，如其論建安文學說:

暨建安之初, 五言騰踴, 文帝陳思, 縱彎以駎節; 王徐應劉, 望路而爭驅; 並憐風月, 狎池 苑, 述恩榮, 敘酣宴, 慷慨以任氣, 否落以使才; 造懷指事, 不求纖密之巧, 驅辭逐貌, 唯 取昭晰之能: 此其所同也。

可見，其 “選文” 批評有時列舉優秀作家同時也列舉作品, 有時僅列優秀作家或舉優秀作 品，且善於從總體上分析一個時代的或一個 “文學發展階段”（頗能突破歷史朝代的分段 法而從文學發展實際出發) 的總體特色, 又能把這種總體特色的分析與作家作品的個性 特色結合起來進行批評。《明詩》篇最後總結最主要的四言詩和五言詩創作特點、文體特 點並加以比較分析說:

故鋪觀列代, 而情變之數可監; 撮舉同異，而綱領之要可明矣。若夫四言正體，則雅潤為本; 五言流調, 則清麗居宗, 華實異用, 惟才所安。

所謂 “鋪觀列代” 就是一種文學史的描述和分析一一實際上這就主要表現為一種特別的 “文 學史”一一各種文體作品的 “精華錄”, 所謂 “撮舉同異” 就是具體作家作品的分析和比較, 這也就上升到 “敷理以舉統” 的高度。這個 “統”, 也主要包括其《通變》篇所說的 “規略文 統，宜宏大體”的內涵。 
（四）知音批評模式: 讀者立場與 “文本” 分析

所謂《文心雕龍》的知音批評模式, 簡要地說, 就是注重文學作品的文本分析, 這是它的 原則和方法, 如聽懂一位音樂家演奏的音樂才能去理解他的內心世界, 如果一個批評家具 備這種鑒賞能力, 那麼他就是那位作家的 “知音”。“知音” 的表面語義, 就是指能夠欣賞 和理解音樂, 欣賞和理解音樂既具有直覺的、感性的特點, 又具有分析的、理性的特點, 這與欣賞和理解文學作品以及其它一切藝術的道理是基本一樣的。順便在此說幾句題外 話, 《文心雕龍》是用駢文寫成的, 從文學創作的角度看, 《文心雕龍》也是很優秀的駢文 作品, 作為一部理論作品, 五十篇當然都是駢文體的 “論說” 文, 能夠令人讀後獲得一種 理性的滿足和智慧的享受, 獲得豐富的乃至系統的知識, 比如《原道》、《時序》、《才略》 等篇章; 另外一些篇章, 我們如果站在一個欣賞文學作品的立場閱讀, 就會感受到劉劦思濃 厚的強烈的感情, 如此的篇章主要有《辨騷》、《明詩》、《詮賦》、《神思》、《風骨》、《情 采》、《物色》等, 《知音》篇也是既充滿冷靜的智慧分析, 又具有強烈的激情。我想劉劦思作 為一個當時的 “文士”, 他也是渴望 “知音” 的, 對千古以來不少優秀的作家, 未能被人理 解或被人誤解乃至被遺忘, 他是感慨萬端的。《知音》篇開端就說: “知音其難哉! 音實難 知, 知實難逢, 逢其知音, 千載其一乎! ”把 《文心雕龍》作為較為典範的駢文作品來進行 研究, 已經有學者作過不少專門分析, 而從文學理論與批評的角度關注《文心雕龍》駢文 的批評 “話語”, 也有不少學者作出不少研究成績。

早期對《知音》篇的分析, 不少論文還停留在對原文的解釋和基本觀點的分析上, 這在《文 心雕龍》全書的研究中也是普遍存在的現象, 但這還只是研究的基礎, 當然是很重要的基 礎。深入的研究成果也不少, 結合全書對《文心雕龍》知音批評進行研究, 也有不少力作。 張少康師對 “六觀” 論作過精要的解釋, 並聯繫《文心雕龍》有關篇章作了閭述: “ “六觀” 是分析文學作品優劣的方法, 而並不是批評標準。” 13 這個判斷是精准的, 關於《知音》 篇 “六觀” 論的研究, 其最重要的爭議是關於 “位體” 的分析。張少康師認為所謂 “一觀位 體” 是指 “要考察文學作品的體裁風格和它所包含的情理是否契合。…… “位體” 的本質是 在情理之安排是否妥當。” 14 又指出: “ “六觀” 從表面上看似乎主要是從藝術形式方面來考 察的, 但是實質上都和內容有不可分割的內在聯熬, 均是由 ‘文’ 以入情” 的具體途徑。” 15 還特別重點強調: “見異唯知音”, 這是劉劦對文學批評理論的一個十分重要的見解。“見 異” 就是要發現作家作品在思想和藝術上的獨創性和不同于其他作家作品的特徵所在。” 16 這些研究和分析已經將劉劦思的知音批評理論的核心精神論述清楚。香港黃維梁先生的《精雕 龍與精工甕———劉劦思和 “新批評家” 對結構的看法》 (下面簡稱黃文 ${ }^{17}$ ), 從 《知音》篇 “六 觀” 的具體內容分析入手, 將之與美國克林斯 - 布魯克斯(Cleanth Brooks)精工翁——詩 結構的研究》(The Well Wrought Urn: Studies in the Structure of Poetry) 一書進

13 張少康師: 《劉圑及其〈文心雕龍〉研究》，北京大學出版社2010年版, 第252頁。

14 張少康師: 《劉妿及其〈文心雕龍〉研究》, 北京大學出版社2010年版, 第252頁。

15 張少康師: 《劉妿及其〈文心雕龍〉研究》, 北京大學出版社2010年版, 第253頁。

16 張少康師: 《劉恓及其〈文心雕龍〉研究》, 北京大學出版社2010年版, 第254頁。

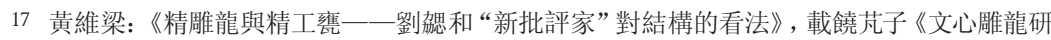
究曾萃》(《文心雕龍》1988年國際研討會論文集), 上海書店1992年版, 第345-357頁。 
行具體比較論述 ${ }^{18}$, 主要觀點認為劉劦思說 “觀位體” 兼及作品的主題、風格、體裁、結構等 理論內容, 認為劉劦 “六觀” 論具有文本分析的客觀性特點, 與新批評的批評理念和方法 有一些類同性, 重視從作品的整體結構和語言修辭進行文學批評。黃文這些分析論述, 我 是基本贊同的。與我討論的論題直接相關的論文，學術界有臺灣蔡英俊先生《“知音” 探 源一一中國文學批評的基本方法》(下文簡稱蔡文) 和顏芘陽先生《《文心雕龍〉“知音” 觀念析論》 (下文簡稱顏文) 這兩篇論文 ${ }^{19}$, 在此需要略加評論, 他們的論文中也概括性 論析了研究現狀, 所以其他涉及本論題的論著我就不再贅述。蔡英俊先生和顏芘陽先生的 這兩篇論文雖然其一些主要觀點存在差異和爭議, 但兩篇論文都從 “知音” 故事的文本分 析入手, 認為《知音》篇是《文心雕龍》的專門的文學批評論, 但恰恰在這一點上兩位作者 都受到的限制, 雖然在論述中也結合《文心雕龍》有關篇章進行分析, 卻因沒有整體關顧全 書來闡述探究《文心雕龍》文學批評的特點, 而造成一些觀點的失誤。這種失誤, 我以為主 要是: 兩位作者都同意 “知音” 概念的內涵具有默契神會的直觀性, 但都認為劉劦 “六觀” 論雖從 “知音” 論述出發, 然而卻轉向客觀分析, “六觀” 論建立的是文學批評的一種客觀的 評判程式, 偏向於語言的修辭分析等, 從而放棄了 “知音” 概念所包含的默契神會的直觀性 方法。在此, 我主要在現有研究基礎上, 簡要討論 “知音” 故事的文本與讀者的立場關係, 如何理解《文心雕龍》知音批評實質是一種文本批評模式等問題。至於《知音》篇一般內容 和觀點全面的解讀式分析, 論者已多, 這裡不再重複。

《呂氏春秋》等劉㤎之前的有關高山流水的 “知音” 故事, 一開始似乎並沒有用 “知音” 這個概念來概括, “知音” 這個概念原是出現在《呂氏春秋・仲冬紀・長見》篇, 其中記載的 是另一個故事:

晉平公鑄為大鐘, 使工聽之, 皆以為調矣。師曠曰: “不調, 請更鑄之。”平公曰: “工皆以為 調矣。” 師曠曰: “後世有知音者, 將知鐘之不調也, 臣竊為君恥之。” 至於師涓而果知鐘之 不調也。是師曠欲善調鐘, 以為後世之知音者也。 20

師曠和師涓, 都是當時著名的精通樂理的樂師。上述的 “故事”, 說明 “知音” 的本義是指 對音樂的理解和樂理的研究掌握。“知” 字的本義也需要推敲, “知” 屬於 “矢” 部的字, 《說 文解字》解釋說: “詞也。從口, 從矢。” 21 清代文字學家段玉裁《說文解字注》補充解釋 說: “識敏, 故出於口者疾如矢也。” 22 《康熙字典》對 “知” 字解釋很豐富, ( “知” 通假 為 “智” 字, 此處不論。) 首先, 增加徐鉉對《說文解字》的補充注釋: “知理之速, 如矢之 疾也。”其次增列義項, 主要有: (1)引《玉篇》: “識也, 覺也。”《增韻》: “諭也”。舉《易・ 繫辭》: “百姓日用而不知。” (引按: “喻” 即曉諭意思。) (2) 又, 相交曰知。舉《左傳・昭公

18 按: 本書已譯為中文本, 《精緻的甕——詩歌結構研究》, 郭乙瑤等譯上海人民出版社 2008 年版。

19 蔡英俊: 《“知音” 探源一一中國文學批評的基本方法》, 顏芘陽: 《〈文心雕龍〉 ‘知音’ 觀念析 論》, 二文均載于吕正惠、蔡英俊主編: 《中國文學批評》(第一集), 臺灣學生書局1992年版, 分別見 第127-144頁, 第195-230頁。

20 許維檛: 《呂氏春秋集釋》卷11《仲冬紀・長見》, 中華書局2009年版, 第254頁。

21 (漢〉許慎著, (宋) 徐鉉等校: 《說文解字》, 上海古籍出版2007年版, 第254頁。

22 (清) 段玉裁撰:《說文解字注》, (江蘇) 鳳凰出版社2007年版, 第401頁。 
四年》: “公孫明知叔孫于齊”; 《楚辭・九歌》: “樂莫樂兮新相知”。(3), 引《廣韻》: “欲 也。” 舉《禮記 - 樂記》: “好惡無節於內, 知誘於外。” (4)又, 猶記憶也。舉《論語》: “父母 之年, 不可不知也。” (5)又, 猶主也。其中舉《左傳・裏公二十六年》: “公孫揮曰: 子產其 將知政矣。” 23 以上說明什麼問題? 是說明了 “知” 是一個 “理解” 現象中的感性與理性結 合的思維活動, 具有表示理解的心靈敏捷性、直接性、感覺性、心理意念的回憶性、欲求性 等含義, 也具有懂得、曉諭、明白、瞭解的意思。簡要地說, “知” 包含直覺性感受之理解和 理性分析之把握兩個方面的內涵，正是從這兩個方面的意思上才能轉換成名詞，所謂 “相 交曰知”、“新相知” (新知, 後來就是指新朋友、新知已的意思), 也正是從上述兩個方面 的意思才能衍生出 “知” 可以作為 “主持” 的意思, 是因為有這個 “能力” 才可以 “主” 事。

至於, “音” 簡要地說就是音樂, 但在中國音樂理論著作中有一些特殊的含義。首先 要瞭解, “音” 與 “詩”一樣, 都是屬於 “言” 部的同部首的字。《說文解字》解釋 “音” 字 說: “聲也。聲生於心, 有節於外, 謂之音。(按: 段玉裁《說文解字注》補充說: 《樂記》 曰: ‘聲成文謂之音”。) 宮、商、角、徵、羽, 聲; 絲、竹、金、石、匏、土、革木, 音也。從言含 一。(段玉裁《說文解字注》補充解釋說: “有節之意也”。) 凡音之屬皆從音。” 24 這意思就 是說, “音” 就是 “言” 字 “含一”, “言” 下不是 “口”, 而是 “口” 字內加一橫, 表示 “聲成 文”, “有節之意” 25 。清代著名學者荁沅作《續釋名》（對漢末劉熙《釋名》的續作）僅兩 大條類, 一, 釋律呂; 二, 釋五聲, 其中 “釋五聲” 中運用 “聲訓” 的方法, 根據漢代班固所 撰《白虎通》解釋說: “聲者, 鳴也, 亦曰五音。音者, 飲也, 言其剛柔清濁而相飲也。” 26 中國古代的音樂演奏所用的樂器, 有絲、竹、金、石、匏、土、革、木等; 演奏音樂, 體現出 宮、商、角、徵、羽五音 (後來發展為七音階) 錯綜、剛柔、清濁的組合成 “文” 的特點, 所 謂 “聲成文”也。《禮記・樂記》說:

凡音之起, 由人心生也。人心之動, 物使之然也。感於物而動, 故形於聲; 聲相應, 故生變; 變成方, 謂之音; 比音而樂之, 及干戚羽施, 謂之樂。樂者, 音之所由生也, 其本在人心之感 於物也。是故其哀心感者, 其聲噍以殺; 其樂心感者, 其聲嘽以緩; 其喜心其感者, 其聲發 以散; 其怒心感者, 其聲粗以厲; 其敬心感者, 其聲直以廉; 其愛心感者, 其聲和以柔。六者 非性也, 感於物而後動, 是故先王慎所以感之者。

這說明儒家把 “聲”、“音” 和 “樂” 是區別開來的, “比音而樂之, 及干戚羽施, 謂之樂”, 即音 樂演奏伴隨樂舞和歌詩吟誦, 而且要按照不同等級禮儀來進行, 所以這就是 “德音”, 《禮記・ 樂記》所謂 “德音謂之樂”, 櫭越這種禮儀制度就是 “禮崩樂壞”。音樂乃人心感物而發, 表 現不同的情感, 所謂 “哀心感者, 其聲噍以殺” 云云, 說明這其間是存在可以把握的規律 的, 存在可以把握分析的原理和客觀因素的。如此, 我們就不難理解劉妿思《知音》篇會提 出 “六觀” 論, 這並不是什麼由主、客觀立場的忽然轉向, 其間本有內在的邏輯存在。正是 從這個 “知音” 的意義上，《禮記・樂記》才使用 “知音” (所謂 “審聲以知音” ) 的概念, 並把音樂與政教結合起來:

23 (清) 陳廷敬、張玉書等編撰: 《康熙字典》, 上海辭書出版社2007年版, 第783頁。

24 (漢〉許慎著, (宋) 徐鉉等校: 《說文解字》, 上海古籍出版2007年版, 第122頁。

25 (清) 段玉裁: 《說文解字注》, (江蘇) 鳳凰出版社2007年版, 第183頁。

26 (東漢) 劉熙著, (清) 畢沅疏證, (清) 王先謙補: 《釋名疏證補》, 中華書局2008年版, 第306頁。 
凡音者, 生於人心者也; 樂者, 通倫理者也。是故知聲而不知音者, 鿖獸是也; 知音而不知樂 者, 眾庶是也。惟君子為能知樂, 是故審聲以知音, 審音以知樂, 審樂以知政, 而治道備矣。是 故不知聲者不可與言音, 不知音者不可與言樂。

至於高山流水的 “知音” 故事, 劉劦《知音》篇肯定是加以關注的, 受到其思想啟迪並從中 吸取理論資源的, 開篇就說: “知音其難哉! 音實難知, 知實難逢, 逢其知音, 千載其一乎! 夫古來知音, 多賤同而思古。所謂 “日進前而不禦, 遙聞聲而相思”也。”從 “古來知音” 這 句表述，可以說明劉妿思開宗明義，就是說 “知音” 就是指通過 “知” 其 “音”（音樂或文學 作品）, 而成為知心的朋友，思想心靈能夠相通的朋友。又說：

夫経文者情動而辭發, 觀文者披文以入情, 沿波討源, 雖幽必顯。世遠莫見其面, 覘文輙見 其心。豈成篇之足深, 患識照之自淺耳。夫志在山水, 琴表其情, 沉形之筆端, 理將焉匿? 故 心之照理, 譬目之照形, 目了則形無不分, 心敏則理無不達。然而俗監之迷者, 深廢淺售, 此 莊周所以笑《折揚》, 宋玉所以傷《白雪》也。

這明確是從讀者角度分析問題, 對於文學作品的讀者來說, 是 “経文者情動而辭發, 觀文 者披文以入情” : 作者一情動一辭發; 讀者一披文一入情。類比知音 (音樂鑒賞批評) : 演 奏者一情動一作曲並演奏音樂來表達情志; 聽者一聽音樂演奏者演奏的音聲一入情。加 以具體分析, 我們馬上就會發現其間存在許多理論上的問題, 有些劉劦思重點論述了, 有些 他就沒有論及, 或者說隱在文本背後, 沒有明說。比如作品是可以反復閱讀的, 是可以超 越時空閱讀的, 所以說 “世遠莫見其面, 覘文軴見其心”，儘管不同的讀者、不同時代的讀 者以及具有各種各樣的區別的讀者, 讀一部文學作品其感性理解和理性判斷都會不同, 文 學史在某種意義上說，確實是流動的，是由讀者參與完成的，但作為語言 “製作” 而成的一 部文學作品, 是可以反復閱讀研究的, 可能存在時空距離很遠、作者身份各異, 而其理解的 結果卻有很多一致的地方。音樂就更複雜了, 因為如果是聽一個音樂家自己作曲自己演奏, 這個過程是隨著演奏者的音響結束而立即結束的, 所謂 “餘音繞梁, 三日不絕”, 那仍然是 讀者的“回憶”和“想像”。因為音樂演奏是一個動態的隨時可以終止的活動。這些問題劉 劦思省略不談。他要談的是文學閲讀、鑒賞和批評問題，他認為從高山流水的“知音”故事可 以說明, 聽音比閱讀要難, 但仍可以 “知音”, 那麼文學作品是語言的製作, 是 “物態化” 的, 那麼更應該能夠予以透徹的“理解”，所謂“況形之筆端，理將焉匿?”這裡他實際上還明 確地解釋所謂 “知音”之 “知”，就是 “心之照理”，“心敏則理無不達”，心敏正是 “知” 的 本義, “達” 就是如董仲舒所謂 “《詩》無達詁”之“達”。

那麼, 所謂 “夫志在山水, 琴表其情”的“知音”故事文本情沉如何呢? 雖然如上述蔡文 和顔文以及許多《文心雕龍》注家都引述文獻, 加以說明, 我覺得還有引述分析的必要。這 個故事說的是春秋時期楚國兩個士大夫伯牙和鐘子期都精于樂理,伯牙善於用琴演奏音樂， 而鐘子期善於聽樂, 琴樂是當時貴族最為重要的教養和身份代表。據漢代高誘《吕氏春秋》 注, 伯牙, “伯, 姓。牙, 名, 或作 “雅” ; 鐘, 氏。期, 名。子皆通稱。悉楚人也, 少善聽音”（《本 味》注）, 又在另一處注曰: 鐘子期乃 “楚人仲儀之族”。《吕氏春秋・季秋紀・精通》篇載:

鐘子期夜聞擊馨者而悲, 使人召而問之曰: “子何擊磬之悲也? ? 答曰: “臣之父不幸而 殺人, 不得生; 臣之母得生, 而為公家為酒; 臣之身得生, 而為公家擊磬。臣不睹臣之母三 
年矣。昔為舍氏睹臣之母, 量所以贖之則無財, 而身固公家之有也, 是故悲也。” 鐘子期歎 嗟曰: “悲夫, 悲夫! 心非臂也, 臂非椎、非石也。悲存乎心而木石應之。” 故君子誠乎此而 諭乎彼, 感乎已而發乎人, 豈必強說乎哉? ${ }^{27}$

這個故事說明, 鐘子期不但 “善聽音”, 而且他還有一套理論, 所謂 “悲夫, 悲夫! 心非臂 也, 臂非椎、非石也。悲存乎心而木石應之。” 其基本觀點與《荺子》中的《樂論》篇和《禮 記》中《樂記》篇等儒家音樂思想是一致的, 都是主張 “樂本於心” 的, 這只要把他說的話 與前文所引《禮記・樂記》的話對照起來分析, 就可以得到證明: 所謂 “凡音之起, 由人心 生也。……樂者, 音之所由生也, 其本在人心之感於物也。”這還說明另外一個問題, 就是劉 劦思《知音》篇總結出 “六觀” 論, 是與《禮記・樂記》以及嵇康《聲無哀樂論》等這樣的音樂 理論文本分不開的, 因為這些音樂理論文本才有對如何 “知樂” 的具體分析。現存文獻中, 高山流水的 “知音” 故事最早見於《吕氏春秋・孝行覽・本味》篇所載:

伯牙鼓琴, 鐘子期聽之。方鼓琴而志在太山, 鐘子期曰: “善哉乎鼓琴, 巍巍乎若太山。”(按: 泰山此指一般的大山。）少選之間, 而志在流水, 鐘子期又曰: “善哉乎鼓琴, 湯湯乎若流 水。” 鐘子期死, 伯牙破琴絕弦, 終身不復鼓琴, 以為世無足複為鼓琴者。非獨琴若此也, 賢 者亦然。雖有賢者, 而無禮以接之, 賢奚由盡忠? 猶禦之不善, 驥不自千里也。 ${ }^{28}$

《呂氏春秋》之《本味》篇主要記述的是伊尹 “說湯以至味” 的故事一一這個對劉劦思知音批 評方法很重要, 下文要分析。高山流水的 “知音” 故事, 穿插在伊尹故事的中間, 令人懷疑 傳世的這個文本可能有 “錯簡” 的問題, 此處不談。其《本味》篇的主旨是如何求得賢能之 才來治理國家, 上述引文的最後一段就是明確闆述這一點的。《吕氏春秋・孝行覽・本味》 篇開端述其主旨曰: “求之其本, 經句必得; 求之其末, 勞而無功。功名之立, 由事之本也, 得賢之化也。非賢其孰知乎事化? 故曰其本在得賢。” 29 漢代韓嬰《韓詩外傳》 (卷九第五 章) ${ }^{30}$ 和劉向《說苑・尊賢》篇, 記載這個高山流水的 “知音” 故事的文本內容與《吕氏春 秋》全同, 其故事結尾的評論也基本一樣, 只是劉向《說苑・尊賢》所載這個故事, 在最後 作: “雖有賢者而無禮以接之, 賢者奚由盡忠哉? 驥不自至千里者, 待伯樂而後至也。” 31 文意更為通暢顯豁。記述故事的主旨和故事結尾的評論, 一般論者多以為與 “知音” 批評 以及 “六觀” 論無關, 從寬泛的一般文學批評研究來說, 確實可以說是無關的, 但從《文心 雕龍》研究來說, 就不是無關緊要的。我一再強調說知音批評要與我在本文中總結論述的 經典批評、才性批評及文體批評結合起來分析，才能得見劉劦思的文學批評的整體的原則和 方法, 其《程器》諸篇中不是一再說明文士的理想問題嗎? 就是《知音》篇所謂 “見異唯知

27 許維撾: 《吕氏春秋集釋》卷9《季秋紀・精通》, 中華書局2009年版, 第254頁。按: 本節所引 文字直接根據許維逼先生校正而改動兩處。

28 許維眮: 《呂氏春秋集釋》卷14《孝行覽・本味》, 中華書局2009年版, 第312頁。

29 許維遏$:$ 《吕氏春秋集釋》卷14《孝行覽・本味》, 中華書局2009年版, 第310頁。

30 參見曹大中: 《白話韓詩外傳》附錄《韓詩外傳》, 嶽麓書店出版社1994年版, 第355頁。

31 引據 (漢) 劉向撰, 趙善詒疏證: 《說苑疏證》卷8《尊賢》第8則, 華束師範大學出版社1985年 版, 第216頁。 
音” 的重要觀點, 也是引述的屈原的本事, 這與 “尊賢” 等評論是有內在聯熬的。高山流水 的 “知音” 故事, 到了《列子》一書中, 這個故事開始在文本上有了明顯的增飾, 《列子》作 者引述這個故事的目的也有了轉變。《列子・湯問》篇記述:

伯牙善鼓琴, 鐘子期善聽。伯牙鼓琴, 志在登高山。鐘子期曰: “善哉! 洋洋兮若江河!”伯牙 所念, 鐘子期必得之。伯牙游于泰山之陰，(按: 泰山此指一般的大山。) 卒逢暴雨, 止於岩 下; 心悲, 乃援琴而鼓之。初為霖雨之操, 更造崩山之音。曲每奏, 鐘子期輯窮其趣。伯牙乃 舍琴而歎曰: “善哉, 善哉, 子之聽夫! 志想像猶吾心也。吾於何逃聲哉? ${ }^{32}$

按: “志想像猶吾心也”, 晉人張湛 “注” 曰: “言心闇合與已心也。”此句中出現 “想像”一 詞, 乃是成詞, 因而 “志” 與 “想像”之間應該可以點斷, 當然 “志” 作為動詞 “記憶”（描 述）等意思來理解亦能使文句通達。張湛把 “志想像” 三字總體理解為 “心”, 大體不差, 即 “你的心印合我的心” 的意思。至於 “吾於何逃聲哉?” 可以意譯為: “我哪裡能隱藏住 我的音樂所表達的心情 (情志) 呢? ” 有譯注者把最後兩句譯解為: “你的意念、思想和想 像與我的心境完全符合, 我要達到什麼樣的境界才能在聲音中隱匿自己的真實情感呢? ”也 大致不差, 但後一句的翻譯容易使人理解為伯牙故意要試驗鐘子期的音樂鑒賞能力, 力圖 隱匿自己的音樂演奏所表達的真實情感, 原文中並無這樣的意思。“吾於何逃聲哉”, 唐人 盧重玄 “解” 曰: “夫聲之所成, 因而感之, 心之所起, 聲則隨之。所以五根皆通, 盡為識 心所傳。善於㯖者, 謦咳猶知之; 況複成于文, 安可不讋耶。” 所謂 “五根皆通, 盡為識心 所傳” 的論述, 明顯是從道家乃至佛學角度的理解, 這當是較為符合《列子》的主旨的。關 於《湯問》篇的主旨, 晉人張湛注曰: “夫智之限知, 莫若其所不知; 而世齊所見以限物, 是 以大聖發問, 窮理者對也。” 唐人盧重玄 “解” 曰: “夫萬物之情, 各貴其生, 不知養其所注 生, (按: “注生”之 ‘注” 字疑誤。) 而愛身以喪其生。故此篇去形全生以通其情, 情通性達 以契其道也。” 33 《列子》是一部道家思想著作, 其從 “去形全生以通其情, 情通性達以契 其道” 的主旨出發來引述知音的故事, 增加了 “伯牙游于泰山之陰”一段的故事, 重點闡明 的是 “志想像猶吾心” 的心印思想, 六朝的佛教禪學 (注意: 不是禪宗) 和東晉時期流行的 佛教大乘般若學 (空宗) 思想以及南朝盛行的佛教涅槃學思想, 都包含有這種心印觀念, 唐宋以後, 佛教中國化更為深廣, 南頓北漸的禪宗興起, 尤其是盛唐就開始佔據主導地位的 南宗禪, 宣揚 “心行處滅”、“言語道斷” 的觀念, 在中國文學批評史上, 唐代僧人也是詩人 的皎然所著《詩式》、南宋嚴羽所著《詩辨》 (《滄浪詩話》) 就直接把佛教 “中道” 論、“妙 悟” 論, 轉化為 “詩家之中道” 論和論詩的 “妙悟” 論, 突出強調審美直覺的思維方式和審美 批評。中國文學批評史上這種以心印心的批評方法和重視心靈體驗的創作論和批評論, 重 視 “言不盡意” 而主張 “不著一字, 盡得風流” 的思想很為流行, 甚至佔據一定的主導地位。

不過, 具體問題要具體分析, 要放在歷史處境中分析, 如劉劦思這樣重視文本批評原則 和方法者也是歷代綿延不絕的，而且經常是與 “妙悟” 論結合在一起的。僅就劉劦《文心雕

32 楊伯峻: 《列子集釋》卷5《湯問篇》, 中華書局1979年版, 第178-179頁。按: “子之聽夫! 志想 像猶吾心也。”此句, 或當在 “夫” 字前點斷。

33 楊伯峻: 《列子集釋》卷5《湯問篇》, 中華書局1979年版, 第147頁。 
龍》而言, 不僅是他採用 “知音” 這個概念來作為討論文學批評具有重視直覺審美體驗的內 涵, 而且在《文心雕龍》中是體現了與 “六觀” 方法融會相洽的 “知味” 批評方法的。知音批 評模式中既包括了 “六觀” 論這樣的具有客觀性的細部批評內涵, 也包括重視 “味” 的整體 體驗和品評的批評理念, 我們一定不可以把這兩個方面僅從《知音》篇的理論內容分析做分 割處理, 甚至忘記了劉劦思的《隱秀》諸篇提出的 “餘味” 論等涵蓋或者說滲入全書中的具體 批評的重要觀點。《呂氏春秋・孝行覽・本味》篇在穿插著名的高山流水的 “知音” 故事後, 緊接著就具體記述了伊尹論 “至味” 的故事:

湯得伊尹, 袚之於廟, 爝以爟火, 覺以爔猳。明日, 設朝而見之。說湯以至味, 湯曰: “可對而 為乎? ” 對曰: “......凡味之本, 水最為始。五味三材, 九沸九變, 火為之紀。時疾時徐, 滅腥 去臊除膻, 必以其勝, 無失其理。調和之事, 必以甘酸苦辛鹹, 先後多少, 其齊甚微, 皆有自 起。鼎中之變, 精妙微纖, 口弗能言, 志弗能喻, 若射禦之微, 陰陽之化, 四時之數。故久而不 弊, 熟而不爛, 甘而不噥, 酸而不酷, 䁍而不減, 辛而不烈, 淡而不薄。……天不可強為, 必先知道。道者止彼在己, 已成而天子成, 天子成則至味具。故審近所以知遠也, 成已所以成 人也。聖王之道要矣, 豈越越多業哉! ”34

所謂 “鼎中之變, 精妙微纖, 口弗能言”, 文學鑒賞和批評不正是這樣嗎? 也就是說文學批評 確有能言的方面, 這是我們在進行文本分析時所強調的 “客觀性” 原則和方法; 但同時文學 批評又確有我們所 “口弗能言” 的方面, 我們只有玩賞體會才能默會於心。劉劦思深知 “伊尹論 至味” 這個故事所言之理, 在《文心雕龍》中不難找到切證。關於《文心雕龍》重視從 “味” 來進行鑒賞分析作品的問題, 學術界研究成果也比較豐富, 如臺灣廖棟樑《滋味: 以味論詩 說初探》以及中國大陸學者有關這方面的論著等 ${ }^{35}$, 我在《藝味說》一書中對這方面的研 究現狀作過總體的評論 ${ }^{36}$, 也列出章節專門探討了《禮記・樂記》、陸機《文賦》、劉劦《文 心雕龍》、鐘秌《詩品》以及其後諸如司空圖等人的 “知味”、“辨味” 的批評論。其實, 如 前所說, 聽音樂家演奏音樂, 能夠聽出其 “調” (和) 與不 “調”, 能夠去把握音樂演奏者 的內心情志 (活動), 與讀者閱讀作品的活動過程, 是具有相同性又具有不同性的。“知音” 之 “知”, 包含著審美經驗和 “研味” (《文心雕龍》中的用語) 過程。“六觀” 是方法, 批評文 學作品從所謂 “一觀位體” 等六個方面去判斷優劣的過程中, 是需要 “諷味”、“玩味” 作品 的內容和形式的整體的 “美感” 的, 是一種 “味其味” 的潛心閲讀、沉浸體會的心理活動。可 見, 其知音批評模式的原則和方法, 本質上是一種 “文本批評”, 其主要內容包括細部分析 和整體把握這兩個有機聯繫的方面。《知音》本是《文心雕龍》中的專篇, 包含豐富的內容, 主要是討論讀者和批評者對作家作品應當如何鑒賞的原則和方法, 應該具有什麼樣的知 識素養, 在文學鑒賞和批評中容易出現什麼樣的錯誤以及其原因是什麼等。《知音》提出 了“六觀” 論, 這實際上也受到漢魏以來人物品評和玄學思想的深刻影響。《知音》篇說:

34 許維頟: 《吕氏春秋集釋》卷14《孝行覽・本味》, 中華書局2009年版, 第312-321頁。

35 (臺灣) 廖棟樑: 《滋味: 以味論詩說初探》, 載呂正惠、蔡英俊主編: 《中國文學批評》(第一 集)，臺灣學生書局1992年版, 第95-126頁。

36 陶禮天:《藝味說》, (江西) 百花洲文藝出版社 2005 年版。 
無私于輕重, 不偏於憎愛, 然後能平理若衡, 照辭如鏡矣。是以將閱文情, 先標六觀: 一 觀位體，二觀置辭，三觀通變，四觀奇正，五觀事義，六觀宮商。斯術既行，則優劣見矣。

從現代文學批評研究來看, 整體上說這是一種 “客觀批評”一一主要立足於作品本身進行 批評, 也就是一種 “本文批評”。加以解析的話, 其中 “一觀位體” 與文體批評有關, “三觀 通變” 與歷史批評 (文學史批評) 有關, 但在 《知音》篇中, 仍然是全新的角度一一因為是如 何能夠成為作家 “知音” 的鑒賞原則和方法, 同時也是專門針對作品本身分析並為創作服務 的。我認為從總體上說，“六觀” 主要體現為 “修辭批評” 方法和 “結構批評” 方法。知音批 評模式, 與前文所說的經典批評模式、才性批評模式、文體批評模式, 都要統觀《文心雕龍》 全書來研究, 這四大批評模式共同構成劉劦思《文心雕龍》的文學批評範式。

\section{三, 結語: 元理論性的總體批評建構}

《文心雕龍》全書分為上下兩篇, 大要可以分為五大理論板塊即: 第一, “文之樞紐” 論, 上 篇前五篇; 第二, “論文敘筆”，緊接其後的二十篇，學術界多稱之為 “文體” 論; 第三，“剖 情析采”, 下篇《神思》(第二十六篇) 至《總術》(第四十四篇) 共十九篇; 第四, 文學批評 論, “文用” 論的 “後五篇”。第五, 全書總序, 即《序志》篇。以上就是所謂 “位理定名, 彰 乎大衍之數, 其為文用, 四十九篇而已。” 37 這種理論體系特徵, 體現了劉劦思的一種 “元理 論” 性質的整體思維特點。“元理論” 就其一般意義而言, 就是指 “試圖將不同時期建立的 用以解釋不同現象的各種理論, 綜合概括為一個具有新原則的更為普遍的理論。” 38 《文心 雕龍》的文學批評, 也體現了一種 “元理論” 的特點, 既具有 “理論化文學批評” 又具有 “實 用文學批評” 等多重特點 ${ }^{39}$, 這體現了劉劦思要系統論述 “文之學” (文學之研究) 的理論 訴求, 所以我認為這體現為一種 “文學批評範式”。之所以借用美國湯瑪斯・沙米爾・庫恩 (Thomas S. Kuhn)的 “範式” 這個概念進行論析 ${ }^{40}$, 是本于劉劦思《文心雕龍》“彌綸 群言” 而 “體大慮周” 的特點來考慮的。《文心雕龍》文學批評範式, 是劉劦思對文學批評所

37 《周易・繫辭上傳》所謂 “大衍之數五十, 其用四十有九。”

38 參見《辭海》 (第六版) 關於 “元科學” 詞條的解釋, 上海辭書出版社2010年版, 第23-38頁。

39 (美) M.H.艾布拉姆斯: 《歐美文學術語詞典》, 其關於 “文學批評” 詞條解釋說, 有理論化文學 批評(theoretical criticism)和實用文學批評(practical criticism), 理論化文學批評的宗旨, “是在 一般批評原理的基礎上, 確立一套統一的批評術語、對作品加以區分歸類的依據, 以及評價作家和作 品的標準。” 實用文學批評 “注重對作家作品的討論。” 等等。中譯本, 朱金鵬、朱荔譯, 同上, 第64-67 頁。

40 (日) 野家啟一: 《庫恩——範式》, 該書《緒論》說: (範式) 無論如何它確實使用了在日 常用語中所指的 ‘對事物的看法’ 乃至 ‘思維的框架這種意思。……庫恩當初賦予 ‘範式” 的意思是 ‘範 式是指在一定時期內可以向研究者群體提供的典範性問題及解法的普遍公認的科學業績, , 即是嚴格 的專業術語。可是在以後的二十年間被擴大為對事物的看法或者 “世界觀” 並加以廣泛傳播……” 中譯 本, 畢小輝譯, 河北教育出版社 2002 年版。按: 在漢語中, 範式和模式比較一致, 本文用批評范式指劉 劦思《文心雕龍》對文學的整體的系統的批評原則和方法, 批評模式指劉劦《文心雕龍》對文學的某一方 
作出的一種總體建構, 無論是經典批評還是才性批評、文體批評以及知音批評的原則和 方法, 都具有貫徹全書的精神和一貫的立場, 從而又環環相扣, 複合共生, 圓融而成為一 種 “圓照之象”, 具有 “範式” 性。這種 “圓照之象”, 是劉劦思最為強調的一種精神、方法、 追求和態度, 是《文心雕龍》文學批評的根本理念, 體現了六朝文學批評的時代特點和最 高水準, 也成為六朝乃至其後一種文學研究的規則。

2014年4月20日初稿, 2015年3月15日修訂於北京

面問題比如作家或作品論等等採用系列的一貫的批評原則和方法, 並滲透整體性的文學批評之中。 特此再加說明。 